\title{
Akademia Zamojska w dziejach i życiu miasta, red. R. Szczygiel i A. Urbański, Zamość 1996, ss. 109
}

Kolejny jubileuszowy tom poświęcony Akademii Zamojskiej. Równieź rezultat konferencji naukowej, która odbyła się 27 maja 1994 roku. Większość materiałów opublikowano w tomie zatytułowanym Akademia Zamojska $i$ jej tradycje.

Niniejszy tom otwiera kazanie poświęcone 400-leciu Akademii wygłoszone przez biskupa Jana Śrutwę.

Kilka rozpraw poświęconych jest budynkowi Akademii (Wiktor Zin, Maciej Pawlicki, Bogumila Sawa). Społeczności Akademii w ży- ciu miasta poświęcił swoje rozważania Ryszard Szczygieł. Halina Wiśniewska zajęła się polskimi tekstami profesorów Akademii, a ks. Bolesław Kumor Wydziałem Teologicznym Akademii w latach 1648-1784, Władysław Froch natomiast zwyczajami i obrzędami weselnymi w XVII wieku w Zamościu w świetle wypowiedzi profesora Bazylego Rudomicza.

Konferencję podsumował Ryszard Szczygiel, a imprezy towarzyszace obchodom rocznicy przedstawił Andrzej Urbański.

(D.Z.-S.)

\section{Dorota Żolądź-Strzelczyk, Peregrinatio academica. Studia mlo- dzieży polskiej z Korony i Litwy na akademiach i uniwersytetach niemieckich w XVI i pierwszej polowie XVII wieku, Wydawnictwo Naukowe Uniwersytetu im. Adama Mickiewicza, Poznań 1996, s. 241}

W serii Psychologia i Pedagogika (nr 106) ukazała się wartościowa rozprawa dotycząca edukacji elit szlacheckich w okresie przedrozbiorowym. Autorka, która poprzedziła ją kilku rozprawkami obejmującymi związki peregrynantów z niektórymi uniwersytetami w Rzeszy, kroczy tropami wytyczonymi przez Stanisława Kota i jego uczniów z Henrykiem Baryczem na czele. Dzieło otrzymało trafny elegancki nagłówek objaśniony w może nadmiernie rozbudowanym - za to precyzyjnym - podtytule. Przeprowadziła gruntowną kwerendę źródlowa (podstawę stanowiły metryki akademickie, wyszła jednak znacznie dalej, sięgając zwłaszcza do memuarystyki i epistolografii, znajdując bogaty materiał np. w testamentach), uwzględniła skrupulatnie dorobek historiografii. Skoro o poprzednikach mowa, godzi się zauważyć, że w środowisku poznańskim sporo do znajomości tematu dorzucił Alojzy Sajkowski. Szczególnie udokumentowane sqa peregry- nacje młodzieży z Korony, znacznym ułatwieniem dla piszącej stało się $w$ odniesieniu do Prus Królewskich opublikowanie dzieła Mariana Pawlaka.

Zasadniczy wyklad (poprzedzony wstępnymi dwoma rozdziałami na temat podróży edukacyjnych oraz uczelni na terenie Rzeszy w okresie stanowiącym przedmiot rozważań) dotyczy statystyki wyjazdów w ujęciu chronologicznym (r. III) i obecności w glównych ośrodkach (Autorka wyszczególniła ich 15) - r. IV, następnie pochodzenia studentów (r. V) i przebiegu studiów (r. VI). Lekturę ułatwiają spisy peregrynantów, wywody dokumentują precyzyjne przypisy oraz bibliografia. Należy żywić nadzieję, że temat Autorka rozszerzy na inne kraje Europy XVI - XVII w. - jak napisałem w konkluzji obszerniejszej recenzji na kamach „Odrodzenia i Reformacji w Polsce” (XX 41 , 1997 , s. $188-190$ ).

Marceli Kosman 